\title{
Should universities be subsidized? - A reference point view
}

\author{
Eva Berde ${ }^{a^{*}}$ \\ a* Corresponding author's e-mail: eva.berde@uni-corvinus.hu
}

\section{H I G H L I G H T S:}

1. My theoretical model shows the welfare consequences of state subsidy to higher education with the recently developed tools of reference point theory.

2. The state university must accept the subsidy and fulfill government's will, but the rector of private university rejects the subsidy if it is unprofitable.

3. The state university shades - deteriorates government's payoff - if her interests are hurt, but the government doesn't shade either of the universities.

4. Two types of errors can occur: In the case of no-subsidization error private university declines the subsidy, but rejection makes society worse off.

5. In the case of subsidization error subsidy is provided, however the increase in welfare is less than the net externality.

\section{Article History}

Received: 02-12-2013

Accepted: 10-12-2013

Available online: 15-12-2013

Product of quick review system.

Keywords:

Higher education;

Subsidy;

Small-scale Enterprise.

JEL Classification:

M130, M160

(C) 2013 The Authors. This is an open access article under the terms of the Creative Commons Attribution License 4.0, which allows use, distribution and reproduction in any medium, provided the original work is properly cited.

\subsection{Introduction}

Studying in higher education not only increases the future welfare of the students, but also provides positive extern effects on the whole society; hence government often subsidizes higher education, and in exchange also tries to enforce its will. An example of this phenomenon can be the higher education in the former communist countries, where a great bulk of university places are still (or were, until the recent years) state financed. In exchange in many cases the state might even interfere with the choice of the rector. In the literature there are instances of dealing with the efficiency effects of the state subsidy in higher education (e.g. Barr, 2004; Johnson, 1984), but in my paper I analyze this question from different point of view: I pay attention to the consequences of universities' behavior, 
induced by supplying certain amount of subsidy. When the question arises: what the welfare consequences of state subsidies are, I try to answer it with the recently developed tools of the so-called reference point theory. Reference point theory - to the best of my knowledge - has not been applied to problems in the area of public relationships, and especially to questions related to state's influence on universities.

The main idea of reference point theory is that contracts could be fulfilled either in perfunctory or consummate ways. While consummate fulfillment of the contract is in the spirit of the contract, perfunctory fulfillment is only strictly according to the prescriptions in the contract. A new term, 'shading' was introduced by Hart (2008), Hart \& Moore (2008), Hart (2009), and Hart (2011). When the realized payoff of one of the parties $(A)$ is worse than what is expected a priori from the contract, then she feels aggrieved and acts in a way that decreases the other party's $(B$ s) payoff, i.e. party $A$ shades on performance. As regards expectations about future payoffs, the initial contract is adopted as a reference point, and these expectations are assumed to be within the boundaries of the contract. Contracts that serve as reference points can prevent parties from shading too much. In my paper I highlight how well reference point theory fits to the relationship between the state and state-owned or private universities. In spite of the simplified assumptions, this setup undoubtedly shows the ambiguous nature of subsidies in higher education.

\subsection{Main relationships}

The participants of my model are the university and the government. Both are represented by one person, the university by the rector (she) and the government by the administrator (he). The initial decisions belong to the administrator. He decides whether he wants the university to work under his ownership, or allows the university to be a private institute. The government also decides on the amount of subsidy, which is represented by $s$. The decision regarding $s$ is based on the biggest difference between the positive external effects from the subsidy and the amount of the subsidy. We assume that subsidizing the university by the amount $s \geq 0$ results in positive externality $e(s)$, where $e(s)$ is the maximum which could be achieved using $s$ amount of subsidy. The function $e(s)$ has the following characteristics: $e^{\prime}(s)>0, e^{\prime \prime}(s) \leq 0$, and there is an $s$, such that $e(s)>s$. Due to these assumptions there exists a unique $s=s^{*}$, for which $\max _{s}(e(s)-s)=e\left(s^{*}\right)-s^{*}$. The benevolent administrator, as a utility maximizer, in our model always chooses $s^{*}$ amount of subsidy, or does not give subsidy at all.

Then the rector of the private university decides whether to accept the subsidy or not. However, the rector of the state university must obey the wish of the administrator. She is obliged to accept subsidy if he offers it to her.

The organizational form is selected in the first stage. Simultaneously, the amount of the subsidy is also determined in this stage. Next, each actor chooses $\mathrm{Y}$ or N, for giving (or accepting) subsidy. We assume that subsidy also means the right to interfere with the rector's policy, and the administrator uses this right to obtain $\left[e\left(s^{*}\right)-s^{*}\right]$ net result of the subsidy. The state owned university must accept what the government wants. The rector of the private university is free to decide whether to accept the subsidy. If she accepts state subsidy she also has to fulfill the state's wishes. To keep my model simple, I abstract away from corruption, asymmetric information and from uncertainty both from the rector's, and from the administrator's part. However, the rector can shade the administrator if she feels aggrieved.

We assume that there is no shading opportunity ex ante, and organizational form is chosen upon tradition and upon the not necessarily rational belief of the benevolent administrator, i.e. he chooses a form what he thinks will result in the highest welfare level to the society. In the long run he always chooses the form of proprietorship which yields the highest welfare, but in the short run there could be deviations from the optimal ownership. When the administrator insists on state ownership it is because he believes it to be the best for the society. Regarding the rector of the state university (motivated by Hart \& Holmstrom, 2010) there is a potential for her ex post shading if she is not satisfied with the subvention. To fix ideas, think of shading as accepting the prescribed number of newcomers entering the university, but not providing them such a high quality of education, which would have been provided otherwise. We show that the state ownership can cause deadweight loss through the shading consequence of the subsidy. The gross result of the decision about subsidy (providing and accepting) can be seen in the matrix below (Figure 1).

Figure 01: Gross Payoffs. Administrator

\begin{tabular}{l|c|c|r} 
& \multicolumn{2}{|c}{ Yes } & No \\
Rector & Yes & $\Delta \Pi_{\mathrm{u}}, \Delta \mathrm{e}_{\mathrm{g}}$ & 0,0 \\
& No & 0,0 & 0,0
\end{tabular}


In Figure $1, \Delta \Pi_{u}$ refers to the gross surplus of the university, and $\Delta e_{g}$ refers to the gross amount of positive externality. We do not lose generality if, similarly to Hart \& Holmstrom (2010), we normalize profits, so that in the 'no' cases gross payoff is zero for both the rector and administrator. In contrast to Hart and Holmstrom (2010), there is no need to distinguish between monetary profit and private benefit, because the administrator cares about each element of social surplus: the total amount of surplus counts for him. Therefore, it does not matter whether the rector's surplus consists of only profit, or both profit and private benefit. Thus, if the rector's private benefit decreases, the administrator will feel himself worse too. The administrator's direct payoff is the positive externality resulting from the subsidy. Gross surplus (gross payoff) does not account for the costs of aggrievement, and consequent shading, which depends on the ex-ante defined organizational form and ex post decisions ( $\mathrm{Y}$ or $\mathrm{N}$ ).

\subsection{Private university}

The rector wants to be subsidized if:

The administrator wants to give subsidy if:

$$
\Delta \Pi_{u}+s \geq 0 \quad \text { Eq. }(01)
$$

$$
\Delta \Pi_{u}+\Delta e_{g} \geq 0 \quad \text { Eq. (02) }
$$

If Eq. (01) and Eq. (02) hold, the social surplus, $W$ equals:

$$
W=\Delta \Pi_{u}+\Delta e_{g} \quad \text { Eq. (03) }
$$

However, when Eq. (02) holds but Eq. (01) does not, the administrator would choose to subsidize, although the rector refuses subsidy, and social surplus is just equal to the university's profit increase:

$$
W=0 \quad \text { Eq. }(04)
$$

We assume that the benevolent administrator never shades. This does not mean that the social surplus wouldn't be higher if the rector accepted the subsidy, but the administrator can not directly hurt participants.

\subsection{State university}

If Eq. (01), and Eq. (02) hold, organizational form does not matter. Social surplus is defined by Eq. (03). However, when Eq. (02) holds but Eq. (01) does not, the administrator can still force the rector to accept subsidy. She must accept the owner's subsidy, and behave according to his wishes, but she will shade. The rector is shading by $\theta(\Delta \Pi+$ $s)$.

Here $0 \leq \theta \leq 1$ is the shading parameter, like in Hart and Holmstrom (2010). Instead of Eq. (02), the government's decision rule will be defined based on whether the next Eq. (05) holds or not:

$$
\Delta \Pi_{u}+\Delta e_{g}+\theta\left(\Delta \Pi_{u}+s\right) \geq 0 \quad \text { Eq. (05) }
$$

If Eq. (05) holds, social surplus - as always in this model - equals the government's net payoff:

$$
\mathrm{W}=\Delta \Pi_{u}+\Delta e_{g}+\theta\left(\Delta \Pi_{u}+s\right) \quad \text { Eq. (05) }
$$

When Eq. (02) holds, but Eq. (01) does not, it means that $\Delta \Pi_{u}+s<0 \leq \Delta \Pi_{u}+\Delta e_{g}$. In the above case, the question emerges whether providing the subsidy was an effective way to increase social welfare. We see the answer to this question in the following section.

\subsection{Subsidy and effectiveness}

Subsidy is most successful if it not only increases the positive extern effect more than its own amount, but also raises the profit of the university. We assume that this happens rarely, because the direct aim of the subsidy was to increase the social usefulness of the university's teaching, and the university's profit was not the question. Increasing the university's profit could be counted as a side influence. The positive extern effect of graduation increases mainly as a result of the expansion of the number of university's students. The subsidy comes together with the state's wish regarding the university's policy, and the rector cannot follow the most profitable strategy for herself. Thus, her profit decreases compared to the case without state intervention. However, the university can be compensated by the subsidy. If the university is at least as well off with the subsidy, as without it, there is no 
shading. The possible scenarios when the university's own profit is negative due to the persuaded policy are summarized in Table 02.

\begin{tabular}{lll}
\hline \multicolumn{3}{l}{ Table 02: The Welfare Effect of the Subsidy, when $\Delta \Pi_{u}<0$. The Case of State University. } \\
Profit & Shading & Social Surplus \\
$\left|\Delta \Pi_{u}\right|<s$ & No & $\Delta \Pi_{u}+\Delta e_{g}>-s+\Delta e_{g}$ \\
$\left|\Delta \Pi_{u}\right|=s$ & No & $\Delta \Pi_{u}+\Delta e_{g}=-s+\Delta e_{g}$ \\
$\left|\Delta \Pi_{u}\right|>s$ & Yes & $\Delta \Pi_{u}+\Delta e_{g}+\theta\left(\Delta \Pi_{u}+s\right)<-s+\Delta e_{g}+\varepsilon$ \\
\hline
\end{tabular}

In Table $02, \varepsilon<0$ is the amount of shading: $\theta\left(\Delta \Pi_{u}+s\right)$. We use the notation $N E$ for the net externality: $N E=$ $-\mathrm{s}+\Delta e_{g}$, i.e. the externality of the subsidy net of the money spent on it. Because of the beginning assumptions, $N E>0$. If the rector has a loss, but the loss (the absolute value of her gross payoff) is less than the subsidy, there is no shading; otherwise she is going to shade. In the case of the state university there are two kinds of deadweight losses:

Type 1 deadweight loss: The decrease of the university's profit is $\left|\Delta \Pi_{u}\right|$, but $W>N E$ still holds.

Type 2 deadweight loss: In addition to the decrease of the university's profit $W<N E$. This scenario is represented in the last row of Table 1.

When type 1 error occurs, deadweight loss does not stop the subsidizing mechanism, in spite of the fact that it decreases the university's direct profit. Altogether, the net result of the subsidy is not deteriorated by shading. However, the emphasis in our model is on the Type 2 error. It shows that, due to the ownership structure, subsidy results in less net social surplus than the difference of positive externality and the amount of subsidy. This type of deadweight loss arises only if the university is in state ownership. Because Eq. (05) holds, the subsidy results in positive social welfare (surplus) even in the case of type 2 deadweight loss. But the social surplus can be very small, and the higher the shading, the smaller the social surplus is. If the social surplus is small, it means very low effectiveness of the subsidy. Using the same $s^{*}$ amount of subsidy could probably result in much more surplus in other areas of the economy. It also has to be taken into consideration that collecting the money for the subsidy is a painful process, which causes deadweight loss in itself, and if money is already collected the sum should be used in more effective manner.

We can call subsidization error the situation when subsidy is provided, but because $W<N E$, the increase in welfare is less than the net positive externality. Subsidization error occurs only if the university belongs to the government, as it was demonstrated above. However there also may exist another type of error, which could be referred as nosubsidization error. The no-subsidization error occurs only in the case of the private university. Because the rector of the private university takes into consideration only her own profit, if Eq. (02) does not hold, she will refuse the subsidy. If subsidy resulted in $W>N E$, than rejecting the material support would make the society worse off. Even if this was the case, the private sector could not be enforced to accept the subsidy.

\subsection{Conclusions}

We analyzed the consequence of subsidy through the relationship of the state and a university. We assumed that subsidy could increase the positive extern effect of university education, taking into consideration the whole number of students who graduates. This effect could be so strong, that even if it decreases the direct profit of the university the society would be better off. We used the reference point framework, established by Oliver Hart and his co-authors (Hart, 20008; Hart, 2009; Hart, 2011; Hart \& Holmstrom, 2010; Hart \& Moore, 2008), to show how the university's rector expresses her aggrievement if she is enforced to accept subsidy. The state can force subsidy, even if it reduces the net payoff of the rector, but the rector shades in such cases. She shades on performance, but still insists on perfunctionary fulfillment of the original contract with the state.

Our model was based on the simplest assumptions, nevertheless we were able to show that there exists a situation when forcing subsidy, and subsequently requiring to follow the state's wishes, could cause harm to the society. In such a case the subsidy is used very ineffectively: the increase of the social welfare is less than the difference of the positive externality (resulted from the state provided money) and the subsidy itself. However, the symmetric situation also exits: declining the subsidy by the rector of a private university can deprive the society the welfare increase which could otherwise be higher than the net effect of the subsidy.

If, in the long run, the organizational form which maximizes expected future surplus of the society is ensured, neither subsidization error, nor no-subsidization error would occur. It is left for future research to investigate how 
adding more sophisticated elements to the model - e.g. taking risk into consideration, assuming not fully benevolent government, etc. - would change the results of this paper.

\section{References}

Barr, N. (2004). Higher education and funding. Oxford Review of Economic Policy, 20, $264-283$. http://dx.doi.org/10.1093/oxrep/grh015

Hart, O. D. (2008). Economica Coase Lecture. Reference points and the theory of the firm. Economica, 75, 404-411. http://dx.doi.org/10.1111/j.1468-0335.2007.00659.x

Hart, O. D. (2009). Hold-up, asset ownership, and reference point. The Quarterly Journal of Economics, 124, 267300. http://dx.doi.org/10.1162/qjec.2009.124.1.267

Hart, O. D. (2011). Noncontractible investments and reference points. (NBER Working Paper Series. 16929). Cambridge, MA: National Bureau of Economic Research. Retrieved September 20, 2012, from http://www.nber.org/papers/w16929.pdf

Hart, O. D. \& Holmstrom, B. (2010). A theory of firm scope. The Quarterly Journal of Economics, 125, $483-513$. http://dx.doi.org/10.1162/qjec.2010.125.2.483

Hart, 0. \& Moore, J. (2008). Contracts as reference point. The Quarterly Journal of Economics, 123, 1-48. http://dx.doi.org/10.1162/qjec.2008.123.1.1

Johnson, G. E. (1984): Subsidies for Higher Education. Journal of Labor Economic, 3, 303-318. http://dx.doi.org/10.1086/298035 